\title{
高再生率アスファルト混合物の 品質確保と安定供給
}

\author{
越 健太郎1 - 今井 龍一2 \\ 1正会員 前田道路株式会社 技術本部 技術部 \\ （干141-8665東京都品川区大崎1-11-3） \\ E-mail:koshi@maedaroad.co.jp \\ 2正会員 東京都市大学 工学部 都市工学科 准教授（干158-8557東京都世田谷区玉堤1-28-1） \\ E-mail: imair@tcu.ac.jp
}

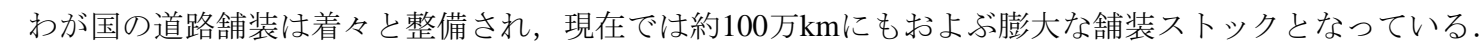
一方, 社会資本整備費は減少しており, この傾向は今後も続くものと予想される。したがって，今後は舗 装ストックの効率的な維持管理と将来にわたり持続安定的なアスファルト混合物の供給が望まれる.

また，近年のアスファルト舗装はリサイクルが進み，再生アスファルト混合物の使用割合が増加すると ともに，再生率も高くなっている。こうした中，このようなリサイクルを品質低下させることなく，持続 的に繰り返していく必要がある.

本研究では高再生率に対応した微細発泡技術および再生用添加剂の発泡技術により, 上記の課題の品質 確保および可使時間延長による供給エリアの拡大を図り，今後の方向性の一案を提言した.

Key Words : microfoaming, foamed asphalt, recycled asphalt mixture, recycling additive, supply area

\section{1. はじめに}

日本の道路舗装は約50年前の高度経済成長期の頃から 現在にかけて着々と整備され，現在の舗装延長は約100 万kmになっている11. 図-1に示すとおり，1980年頃から は舗装新設費，1990年代半ばにかけてからは舗装維持修 繕費が減少に転じている．そのような中で今後この膨大 な社会資本ストックを持続安定的に維持管理していかな ければならない。

本研究では，維持管理の根幹を担う舗装材料の持続的 再生利用に着目した。繰り返し再生可能な舗装材料であ るアスファルト混合物は，少資源国の日本にとって国家 の資財である. そのため, 膨大な道路の舗装ストックが 老朽化していく中で, 舖装材料の品質を保ちながら持続 的に有効利用していかなければならない. かつて経験し たことのない維持管理時代を迎える中で, 再生アスファ ルト混合物をより最適化する技術向上が求められる。 ま た，建設投資削減によってアスファルト混合物の生産量 が減少している.これに伴って合材工場も減少し，将来 的に地域によってはアスファルト混合物の供給不安が懸 念される. アスファルト混合物の運搬は 2 時間程度が限 度であるため，工場からの供給範囲が限られることから，
今後の維持管理にとって主な課題であり，持続安定的な 供給対策も併せて考えていく必要がある.

これらの課題に対して本研究では，これまでCO $\mathrm{C}_{2}$ 排出 量削減として取り組まれてきた中温化混合物に注目した. 中温化混合物はアスファルト混合物製造時の製造温度を 下げて製造して $\mathrm{CO}_{2}$ 排出量を抑制するだけではなく, 製 造温度の低下によりアスファルト性状の劣化も抑制され る. アスファルト混合物のアスファルトの劣化は製造時 の熱劣化が大きな要因を占めることから, 製造温度の低 下はアスファルト混合物の品質低下の抑制に大きく寄与 する2). 一方，中温化技術の使用によりアスファルト混

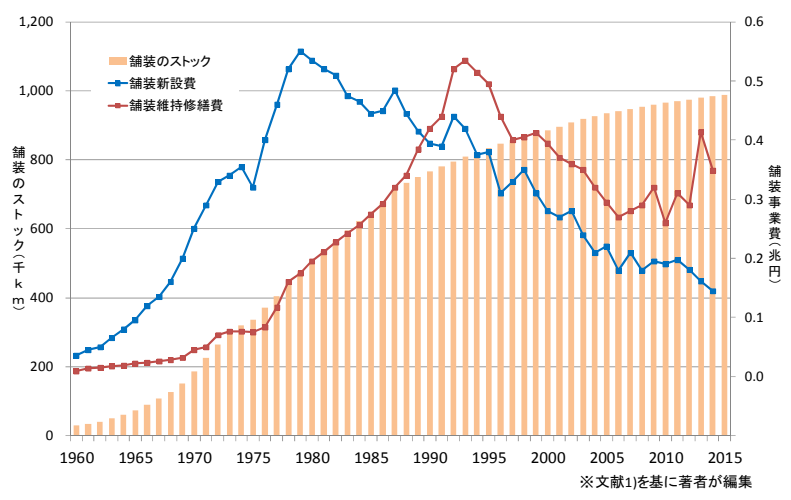

図-1 舗装ストックと舗装整備費の推移 
合物の可使時間を長くすることも可能である. 混合物の 温度が低い状態においても, 締固めが可能である特性を 活かし, 通常のアスファルト混合物と比較して, より長 い時間使用することができる.

中温化技術にはいくつかの方法があるが3)，大量製造 やコストを考慮すると，欧米で普及しているフォームド アスファルトが最も適していると考えられる. しかし， 日本では, 再生アスファルト混合物のアスファルト再生 骨材の配合率 (再生率) が高く, フォームドアスファル 卜を適用しても新たに加えるアスファルトの量（新アス ファルト量）が少なくなり, 中温化効果も小さくなる. 佐々木ら ${ }^{4} の$ 研究においても再生率の増加に伴い締固め 改善効果が減少寸ると指摘されている. そのため, 日本 で適用させるには，高い再生率で効果を発揮できるよう に改良する必要がある.

本研究の目的は, 持続的に繰り返し再生可能な高再生 率アスファルト混合物の開発と，その技術を活かした安 定供給可能なエリアを拡大寸る戦略的なメンテナンス計 画のアプローチの提案とした.

本論文の構成として, 第2章および第3章では, 再生ア スファルト混合物の状況を調査し, 品質向上に関寸る課 題を分析する. 第4章および5章では, 日本に適した高再 生率用のフォームフォアスファルト技術の開発およびそ の効果を示す．第6章では開発したフォームドアスファ ルトを合材工場で検証し，ダンプトラックでの運搬時間 やサイロでの貯蔵時間の効果を述べる. 第7章ではこれ までの結果に基づき，今後の安定的なアスファルト混合 物の供給体制の構築に向けた方向性を考察する. そして, 第8章で本研究のまとめと今後の展望を述べる.

\section{2. アスファルト混合物の状況}

図-1 に示したように, 近年の道路舗装整備費は減少 傾向にある. その影響により, 日本国内のアスファルト 混合物製造数量は年々減少している. 日本アスファルト 合材協会の調査 ${ }^{5}$ によると, 図-2 に示すとおり, アスフ アルト混合物の製造数量は 1992 年時のピーク時には約 8,000 万トン製造されていたが，2015年度には約 4,200 万 トン（ピーク時の約 53\%）まで減少してきている.

2020 年には東京オリンピックが開催されるため, 多 少の需要の増加は期待できるが，全体的には今後もしば らくは減少傾向が続くと推測できる.

図-3に再生アスファルト混合物の再生率の推移を示す. 近年, 再生率は国内平均で約 $50 \%$ まで上昇している. ま た都市部などの地域によっては75\%の高い再生率で使用 されている例もある.

このように日本では再生アスファルト混合物が主流で

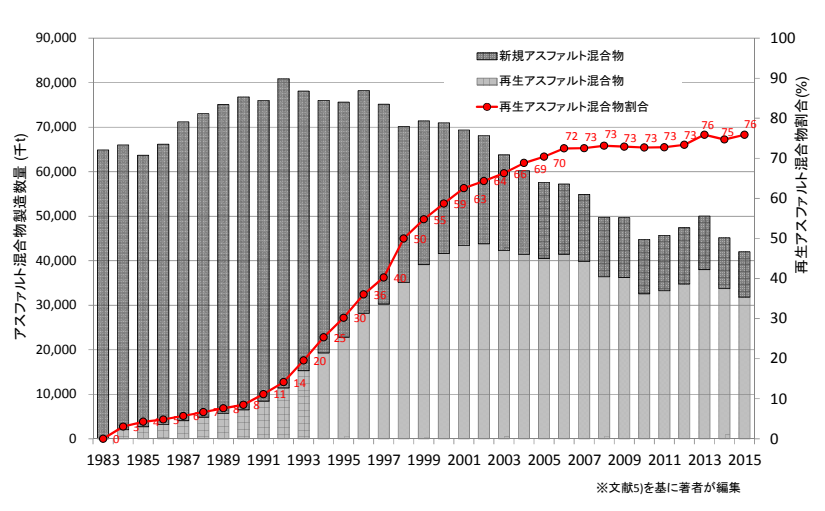

図-2 再生アスファルト混合物と再生割合の推移

あり，再生骨材の使用割合が非常に高い．このような状 況から今後, 再生アスファルト混合物の品質の低下も䀣 念されている. 将来にわたり持続的に再生を繰り返して いくためには新たな技術導入が求められている.

\section{3. 再生アスファルト混合物の品質向上方法}

持続的な繰り返し再生には再生アスファルト混合物の 品質を向上させなければならない. 再生アスファルトの 品質を向上させるために考えられる主な課題は以下の 2 点である.

(1)製造時の温度を低下させてアスファルトの劣化を抑制 させる.

(2)再生骨材に付着している劣化したアスファルトを効率 的に回復させる.

製造時の温度低下は，アスファルトの劣化を抑制させ るだけではなく, 製造時のCO 排出量の削減やアスファ ルトフューム発生抑制による作業環境改善などの効果が 見込まれる．また，単に製造温度を下げるだけではなく， 低い温度でも施工がしや寸く，締固めが十分できる耐久 性のある高品質な再生アスファルト混合物の開発を目指 すため, 再生骨材の旧アスファルトを効率的に回復させ る必要がある. これにより, 施工時の混合物の温度低下 に伴う施工不良等の品質低下も抑制でき, 高品質な再生 アスファルト混合物になると考えられる.

このため, 混合物の品質面からアスファルトの劣化を 抑制し，かつ，施工時の温度低下による品質低下の抑制 の両面からのアプローチにより, 総合的に舗装の耐久性 向上や長寿命化に寄与するものと考える.

この課題に対する方法としては中温化技術が考えられ る. 日本では以前よりアスファルト混合物の中温化に取 り組んではいるが，主に添加剤方式が主流である. 添加 剂方式の中温化は, 効果も期待でき, 大きな設備も必要 としないため手軽に導入できるが，中温化剂が高額なた め，アスファルト混合物の価格が上がってしまう。 今後, 
一般的に再生アスファルト混合物一使用するには，大量 製造に対応しアスファルト混合物のコスト上昇が極力抑 えられる技術でなくてはならない.

これらの条件にあてはまる技術としては，欧米で中温 化技術として普及しているフォームドアスファルトが最 も適していると考えられる。しかし，日本においては， 2章で述べたとおり, 再生アスファルト混合物の再生率 が高い.このためフォームドアスファルトを適用しても 発泡させる新たに加えるアスファルト（新アスファルト） の量が少なくなるため, 中温化効果も小さくなる. その ため, 高い再生率に適用させるには，フォームドアスフ アルトの中温化効果が欧米の技術より高くなるように新 たに効果の高いフォームドアスファルト技術を開発する 必要がある.

そこで，本研究では，日本の高再生率に対応したアス ファルトの微細発泡技術を開発した。.さらに，中温化効 果の向上と再生品質の向上を目指した再生用添加剤の発 泡技術を開発した。

\section{4. 微細泡フォームドアスファルト}

フォームドアスファルトは, 高温のアスファルトが水 と混合され，発泡することで生成される．この時，アス ファルトの容積が増加し見掛けの粘性が低下寸るために, 製造時には混合性が向上寸る，施工時に容積は元に戻る が，残存する泡のベアリング効果によって締固め性が向 上する．さらに施工後に温度が低下寸れば，泡の影響は なくなり, 混合物の品質は確保される. しかし, 高再生 率の再生アスファルト混合物は新アスファルト量が少な いため効果が低下寸る．したがって，フォームドアスフ アルトを再生アスファルト混合物に適用するためには,

フォームドアスファルトのベアリング効果を高める必要 がある. 図-4は従来のフォームドアスファルトと微細泡 に改良したフォームドアスファルトの概念を示したもの である. 従来のフォームドアスファルトは, 発泡・膨張 した後，比較的粒径の大きな泡同士が結合・肥大化する ことにより消滅し，施工時における泡の残存量が減少す る傾向にある. この泡の残存量を増やし， ベアリング効 果を高めるためには, 微細泡化することが望ましいと考 えられる。

\section{（1）フォームドアスファルトの改良}

フォームドアスファルトを微細泡化するため, アスフ アルトの発泡状態を改善させるための添加剤（以下，発 泡補助剤）を使用することとした．各種材料を実験した 結果, 表-1に示寸ような発泡補助剤の使用によって発泡 状態が大幅に改善され，これまで課題であった大きな泡

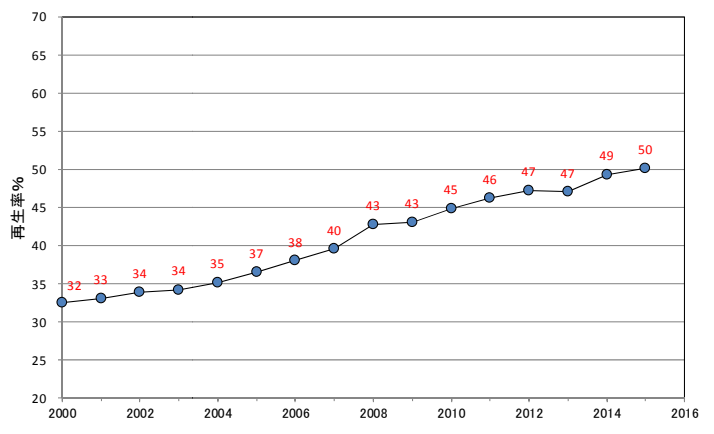

図-3 再生アスファルト混合物の再生率の推移

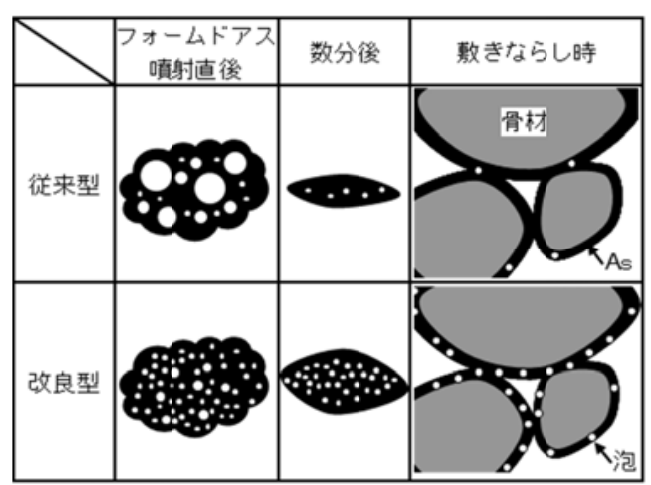

図-4 フォームドアスファルトの概念

表-1＼cjkstart発泡補助剤の性状

\begin{tabular}{l|c}
\hline \multicolumn{1}{c|}{ 項 目 } & 性状值 \\
\hline \hline 形状 & 液体 \\
\hline 動粘度 $\left(25^{\circ} \mathrm{C}\right) \mathrm{mm} 2 / \mathrm{s}$ & 100 \\
\hline 密度 $\left(15^{\circ} \mathrm{C}\right) \quad \mathrm{g} / \mathrm{cm} 3$ & 0.97 \\
\hline 引火点 $\quad{ }^{\circ} \mathrm{C}$ & 315 \\
\hline
\end{tabular}

表-2 発泡倍率と持続時間

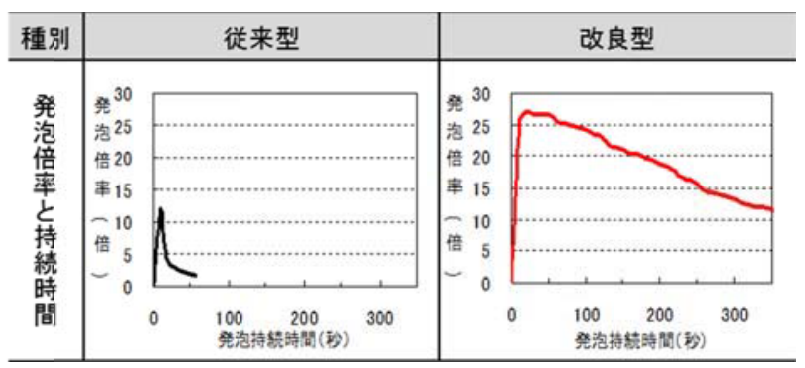

を抑制し，大量の微細泡が存在するフォームドアスファ ルトに改良することができた. フォームドアスファルト の性状の発泡倍率と持続時間を測定した結果を表-2に示 す. 開発品は発泡倍率，持続時間ともに大きく改善され ていることが確認できる.

なお，発泡補助材はアスファルトに対して0.1\%程度の 添加量であり，アスファルトの性状に影響を与えること もなく，アスファルト混合物としての価格の上昇も $1 \%$ 
程度である.

\section{（2）改良したフォームドアスファルトの効果}

改良したフォームドアスファルトを使用したアスファ ルト混合物（フォームド混合物）の効果を検証した.

\section{a）新規アスファルト混合物}

図-5は通常のアスファルトと従来型のフォームドアス ファルト，改良型のフォームドアスファルトを使用した 時の密粒度アスファルト混合物（13）の締固め温度と締 固め度の測定結果である。なお，アスファルトはストレ ートアスファルト60/80を使用した。

この結果から，通常のアスファルトを使用した混合物 より，従来型のフォームドアスファルトを使用した混合 物は締固め効果が高いことがわかる. また改良型のフォ ームドアスファルトは，従来型よりさらに効果が改善さ れている.

製造温度低減効果は従来のフォームドアスファルトで

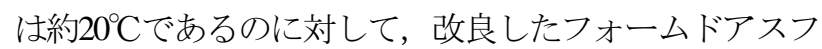
アルトでは約 $30^{\circ} \mathrm{C}$ ときく改善されている.

ポリマー改質アスファルトでも図-5と同様の傾向を示 しており，製造温度低減効果を確認した，各改質アスフ アルトを使用した時の製造温度低減効果を表-3に示寸。

\section{b）再生アスファルト混合物}

フォームドアスファルトの再生アスファルト混合物へ の適用を検討した．図-6は再生骨材配合率を変化させた 時の製造温度低減効果を示している．改良型のフォーム ドアスファルトを使用した混合物は従来型のフォームド アスファルトを使用した混合物よりも，製造温度低減効 果は高い. 従来型のフォームド混合物は再生骨材配合率 が60\%の時の製造温度低減効果が $5{ }^{\circ} \mathrm{C}$ 程度しかないのに 対して, 改良型のフォームド混合物は $25^{\circ} \mathrm{C}$ 程度の低減効 果がある. したがって, 改良型のフォームドアスファル 卜は再生アスファルト混合物でも十分な効果が確認され た.

\section{5. 高再生率再生アスファルト混合物への適用}

第4章の結果から，フォームドアスファルトを微細泡 へ改良することにより再生アスファルト混合物に対して 締固め性が向上し，製造温度低減効果が十分に得られる ことが確認できた．しかし，図-7に示寸とおり，再生率 が高くなると新アスファルト量が少なくなる影響もあり， 効果が小さくなる，そのため，高再生率の混合物に対し ては，改良したフォームドアスファルトでも適用効果を 十分に出すことは難しい，本研究ではより高い再生率へ 適用するためにはさらに効果の上乗せが必要だと考えた. そこで，再生アスファルト混合物に使用している再生

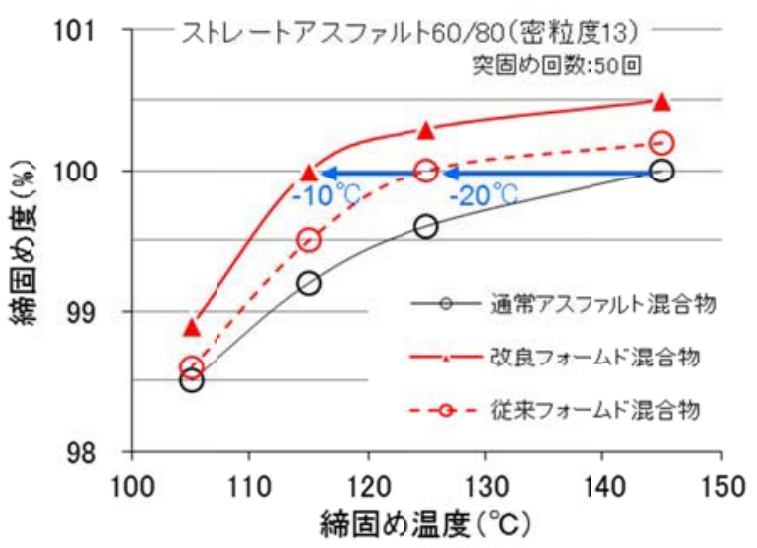

図-5 締固女温度と締固め度の関係（新規混合物）

表-3 改質アスファルトを使用した混合物の温度低減効果

\begin{tabular}{c|c|c}
\hline $\begin{array}{c}\text { アスファルト } \\
\text { の種類 }\end{array}$ & 混合物の種類 & $\begin{array}{c}\text { 温度低減効果例 } \\
\left({ }^{\circ} \mathrm{C}\right)\end{array}$ \\
\hline 改質 I型 & $\begin{array}{c}\text { 密粒度アスファルト } \\
\text { 混合物(13) }\end{array}$ & 29 \\
\hline 改質H型 & $\begin{array}{c}\text { ポーラスアスファルト } \\
\text { 混合物(13) }\end{array}$ & 22 \\
\hline
\end{tabular}

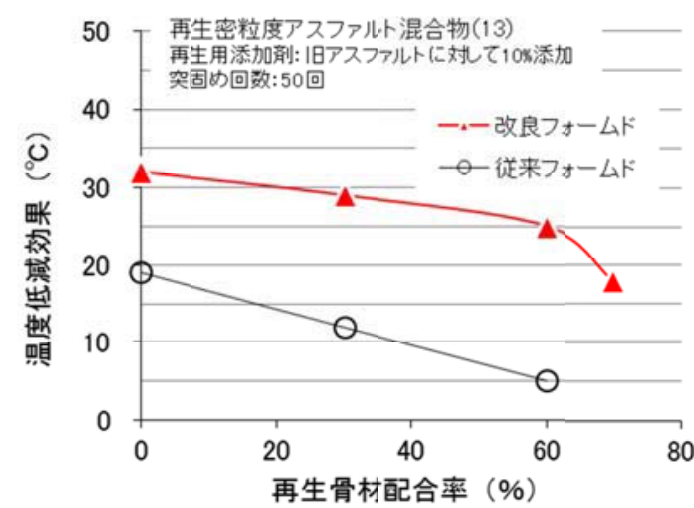

図-6＼cjkstart再生骨材配合率と温度低減効果の関係

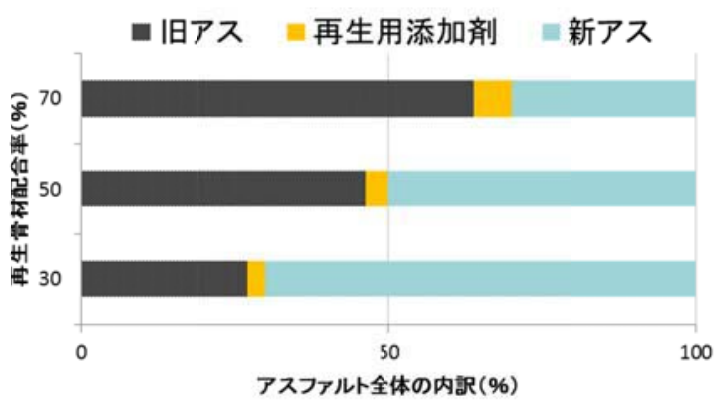

図-7＼cjkstart再生アスファアルトの構成

用添加剤に着目した，再生用添加剂は図-7のように，再 生骨材配合率が高くなると添加される再生用添加剤の量 は増加していることがわかる。 このことから，アスファ ルトの一部となる再生用添加剽を発泡させることにより， 製造温度低減効果の上乗せ効果を得られると考えた。

また，再生用添加剤を発泡させることは表-4に示すよ 
うに，泡のベアリング効果による混合物の製造温度低減 効果を向上させるだけではなく, 見掛け上の容積が増加 した状態で添加することにより，混合直後から再生用添 加剤の旧アスファルトに対する被膜状態が良好であり， 旧アスファルトの性状が回復しや寸いものと考えられる.

これらのことから，再生用添加剂をアスファルトと同 様に発泡させることにより, 高再生率アスファルト混合 物の製造温度低減効果および再生骨材の品質回復が効果 的に図られるものと考えた。

\section{（1）フォームド再生用添加剤の製造温度低減効果}

フォームド再生用添加剂を用いた再生アスファルト混 合物の締固め特性を評価した. アスファルトは(1)通常の アスファルト，(2)アスフルトのみフォームド（Sフォ 一ムド），(3)アスファルトと再生用添加剤ともにフォー ムド（Wフォームド）で比較した結果を図-8に示す．W フォームドすることにより，Sフォームドより締固め特 性が改善され, 本検討条件では温度低減効果が約 $8{ }^{\circ} \mathrm{C}$ 改 善された.

\section{（2）フォームド再生用添加剤の性状回復効果}

再生骨材の旧アスファルトの回復状況を評価するため に, 圧裂試験にて効果を確認した。 ただし，本研究では 効果を明確にするため再生骨材の久を使用した．試験結 果を図-9に示す，圧裂係数は密度に依存するため, 密度 と圧裂の傾向線で比較した. 通常添加では添加1時間後 と5時間後の傾向に違いがある. これは, 経過時間が長 くなると, 再生用添加剤がよく馿染むことにより旧アス ファルトの性状が回復し厓裂係数が小さくなっていると 考えられる. これに対して発泡添加では, 添加1時間後 と5時間後について, ばらつきはあるものの同様の傾向 がみられる．また，発泡添加の添加1時間後，5時間後は 通常添加の5時間後之同様な傾向がみられる.

このことから，発泡添加は旧アスファルトと急速に馴 染むことが示唆される. 今後の課題として, 試験を重ね て効果を検証していくことが挙げられる.

\section{6. アスファルト合材工場における効果の検証}

\section{（1）フォームドアスファルト発生装置}

これまでのフォームドアスファルト混合物の結果を基 に，既設プラントにも容易に設置ができ，簡素で小さく 納まるフォームドアスファルト発生装置を開発した.

発泡状態の良いフォームドアスファルトを得るために はアスファルト中に均一に水を分散させる必要がある. このような発生装置はいくつか種類があるが，大別する とチャンバー式と配管式がある。それぞれの方式を検討
表-4 添加方法による分散・被膜状態の違い
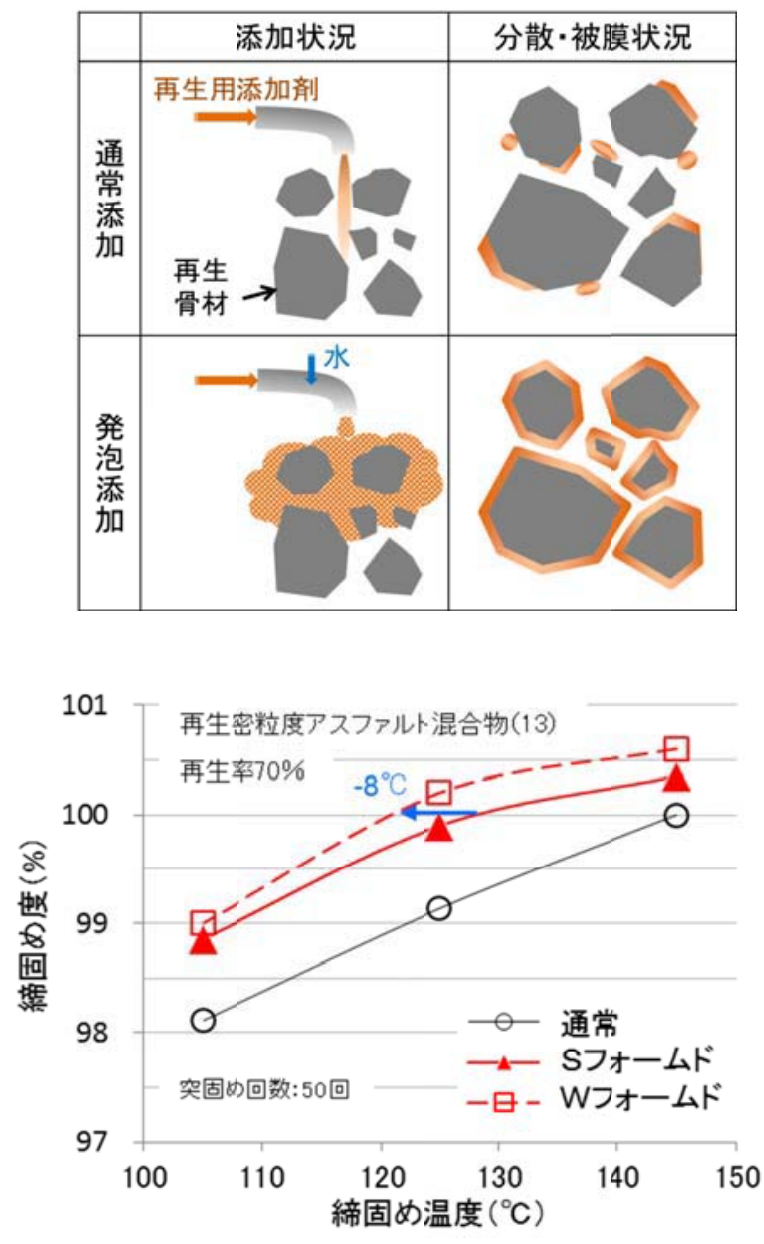

図-8 締固め度試験結果（Wフォームド効果）

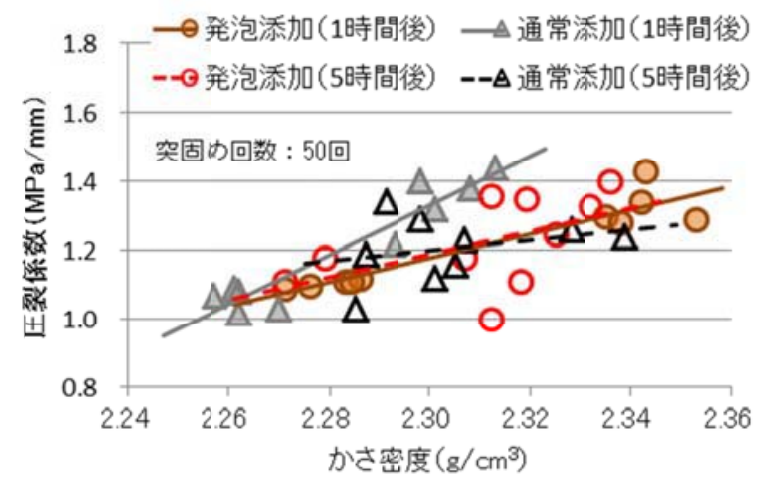

図-9 密度と圧裂係数（再生骨材, 再生用添加剤の夕使用）

した結果，小型で整備性もよく再生添加剤の少量噴射に も対応できる配管式を採用した．発泡補助剂を配管内で 添加させラインミキサーで混合できる方式とし，既設の 配管途中に約 $1 \mathrm{~m}$ の幅で納まる仕様とした. 図-10に配置 図を示す。

\section{（2）フォームドアスファルト効果の持続}

開発した発生装置を合材工場に設置し，フォームドア スファルト混合物の持続効果を検討した，合材工場には 
アスファルトと再生添加剤用の発生装置をそれぞれ設置 し，Wフォームドで検討した.

\section{a）ダンプ運搬試験}

ダンプ運搬試験は図-11に示すようにアスファルト混 合物積載後1時間毎に5時間までサンプリングした。なお, サンプリング以外の時間は合材工場周辺を走行すること とした.アスファルト混合物の評価は，マーシャル安定 度試験供試体の締固め度により検証した。

Wフォームドの再生アスファルト混合物は，製造直後 から通常アスファルト混合物に比べて高い締固め度を示 しており，運搬時間が経過しても締固め度はほぼ同一の 值で推移した.

このことから，ダンプ運搬中に時間が経過してもアス ファルト中に含まれる微細泡は減少せず，発泡によるべ アリング効果が持続していることが確認でき，長距離運 搬において効果的なアスファルト混合物であるといえる. b）サイロ貯蔵試験

サイロ貯蔵試験は図-12に示すように貯蔵後6時間毎に 30時間までサンプリングし，マーシャル安定度試験供試 体により締固め度を測定した。 まず，再生骨材配合率が 70\%と高い再生アスファルト混合物は，Wフォームドの 使用により $20^{\circ} \mathrm{C}$ 以上の温度低減効果が確認できた。また， ダンプ運搬試験の結果と同様に，サイロ貯蔵に伴い時間 が経過しても発泡によるベアリング効果が持続されてい ることが確認できた.

\section{7. フォームドアスファルト混合物の展開}

本研究では合材工場の数を過去30年遡り 2015年までの 推移を調査した5)。図-13は，調査結果である合材工場の プラント基数と経営会社との推移を示している. 図より, アスファルト混合物の製造数量の減少に伴って，合材工 場の数も減少していることがわかる.1990年のプラント 基数が1938基に対して2015年は1145基とピーク時の約6 割に減少している.これまでの合材工場数の推移から， 今後も合材工場は横ばいもしくは減少していく可能性が あると推察される.

今後，アスファルト混合物の製造数量が減少し，合材 工場の統廃合が進むと, アスファルト混合物を供給でき なくなる圈域 (空白圈域) が生じ, この圈域が拡大して いくことが獎念される.

しかし, 空白圈域が生じても道路の維持管理を必要最 低限行わなくては，国民生活に支障を来し，経済活動に も影響する.このため, 将来にわたり日本全域へアスフ アルト混合物を持続的に安定供給していく必要がある. 本章は, アスファルト混合物の供給圈域の維持に係わる 今後の方向性や課題を考察する.

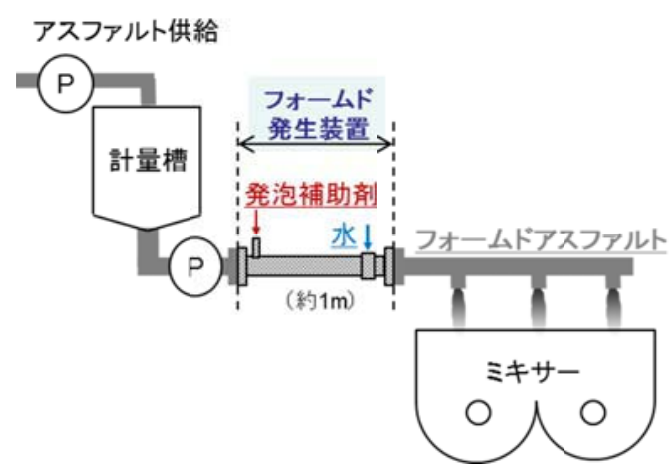

図-10 フォームドアスファルト発生装置の配置図

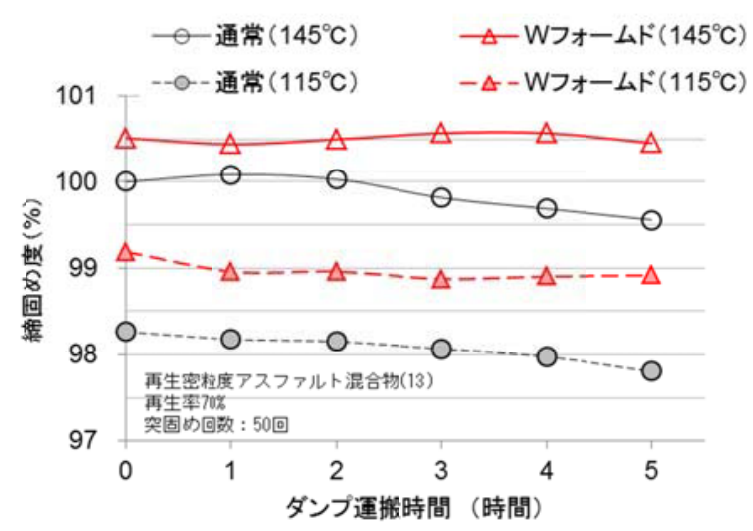

図-11 締固め密度測定結果（ダンプ運搬試験）

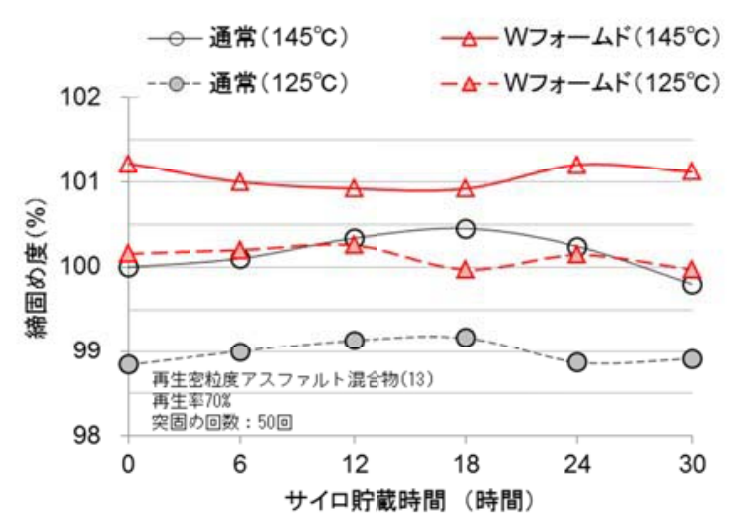

図-12＼cjkstart締固め密度測定緹果（サイロ貯蔵試験）

\section{（1）フォームドアスファルト技術の活用}

本節では、今後のアスファルト混合物数量減少対応の 一方策に寄与するアプローチを考察する. 理想的な対応 としては，全国の道路網に対几て合材工場の供給範囲を 踏まえて，最適に合材工場を配置することであるが，民 間経営の合材工場でそのような再考は現実的ではない.

現実的実行可能な合材工場側からのアプローチとして， アスファルト混合物の改良により，運搬距離の延長を図 る取り組みが有効と考えられる。第6章で述べたとおり， フォームドアスファルト技術を用いたアスファルト混合 
物は運搬時間の延長や長時間サイロ貯蔵の有効性が認め られる.この技術を用いた長距離運搬による合材工場供 給エリア拡大の概念を図-14, サテライトサイロ活用の 概念を図-15に示す.

長距離運搬に関してはフォームド混合物を用いて運搬 時間を延長させる．例えば運搬時間を1.5倍延長できれ ば2時間圈域から3時間圈域へ大きく供給エリアを拡大し て供給することができる，また，サテライトサイロの活 用では供給エリアの需要が減少した工場をサテライト化 することにより工場経費を削減でき，かつメイン工場供 給工場は供給範囲の拡大とアスファルト混合物製造量の 安定化を図ることが期待できる.

\section{（2）アスファルト混合物の供給圏域のマネジメント方}

\section{策の確立}

アスファルト混合物の製造数量減少に伴い，供給が困 難な空白圈域の有無，フォームドアスファルト技術によ る供給圏域拡大でどの程度まで対応できるのかなどの供 給圏域を道路種別毎にできる限り正確かつ定期的に把握 していく必要がある。

図-16は，道路ネットワークデータを用いた道路種別 毎の供給圈域の算出イメージを示している.このような 算出ができると，現行の合材工場に基づくアスファルト 混合物の供給圈域の実態把握に加え，供給圈域の維持の ために運営継続が必須となる合材工場の特定も可能とな る.したがって，アスファルト混合物の供給圈域の現状 把握および将来予測を可能とする戦略的な供給マネジメ ント方策の確立が今後の重要な課題としてあげられる.

\section{8. まとめ}

本研究は，社会資本整備の要である道路舗装の維持管 理に久かせない再生アスファルト混合物の品質向上およ び持続的安定供給に対応するため，中温化技術であるフ オームドアスファルト技術を用いる方策を示した。

第2章ではアスファルト混合物の状況を確認し，第3章 では品質向上の方法としてフォームドアスファルト技術 を選定した．第4章ではフォームドアスファルト技術を 日本の高再生率用に改良した。第5章では改善効果を高 めるために再生添加剤の発泡に取り組み, 再生骨材の回 復効果を見出した．第6章では実際の合材工場にフォー ムド装置を設置して長距離運搬およびサイロ貯蔵時間の 延長効果を確認した.

第7章ではこれまでのアスファルト混合物製造状況から， 今後の供給のあり方を考察した.

フォームドアスファルト技術は，アスファルト混合物 の中温化製造技術として，地球温暖化防止，フューム低

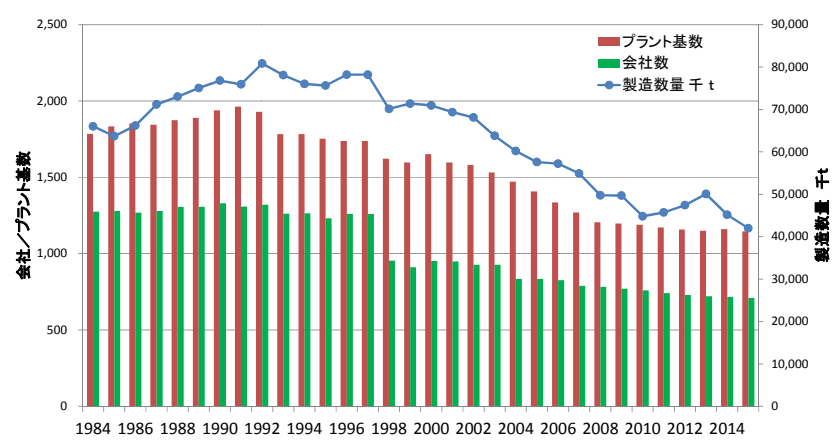

図-13 アスファルト合材工場の推移

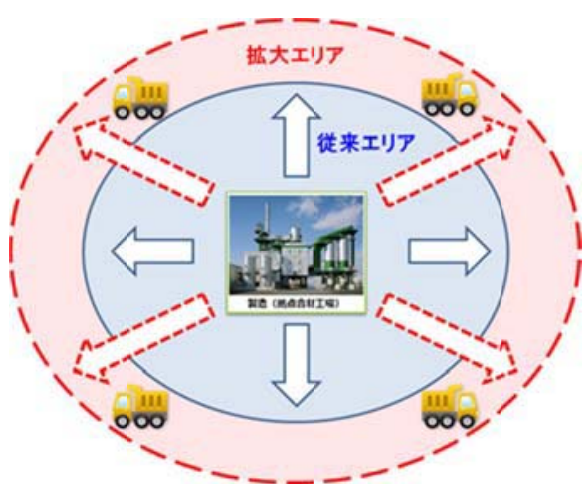

図-14 合材供給エリア拡火の概念（長距離運搬）

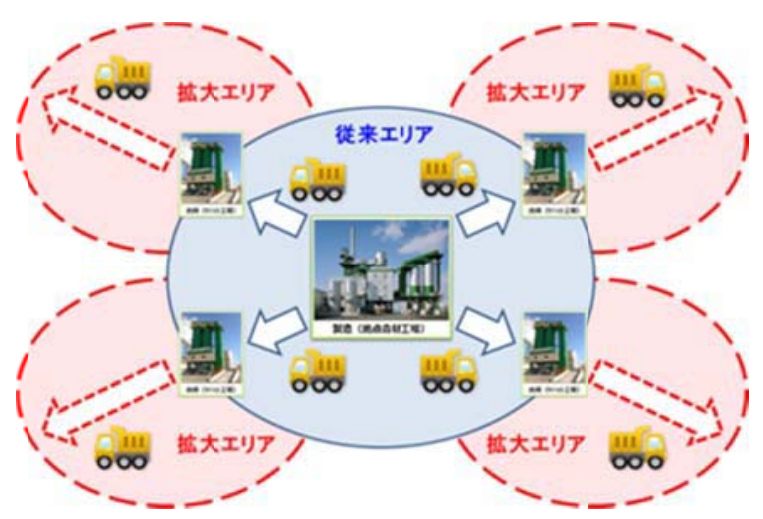

図-15 合材供給エリア拡大の概念（サテライトサイロ活用）

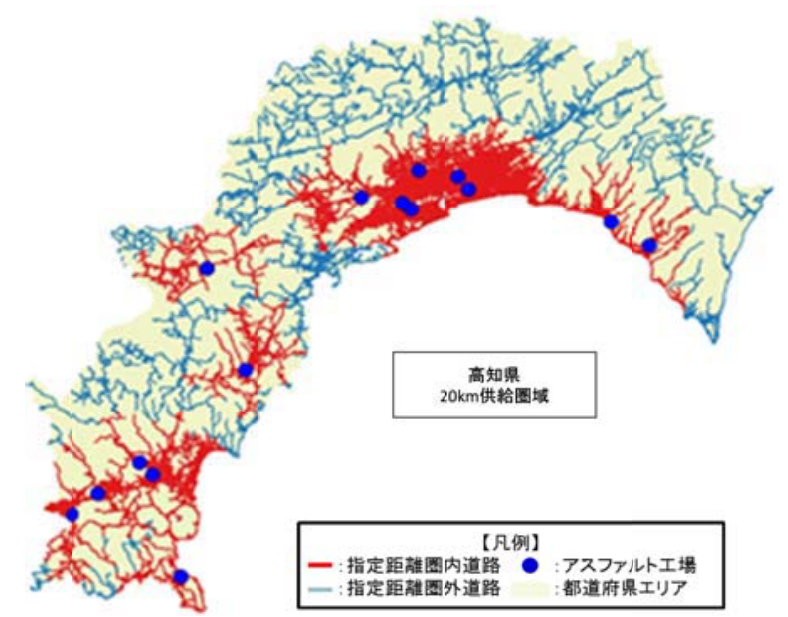

図-16 アスファルト合材の供給圏域の算出イメージ 
減による健康被害低減，そして，再生アスファルト混合 物の品質向上に有効な技術であると考える. 特にアスフ アルトの熱劣化抑制は将来にわたり持続的な繰り返し再 生を行う上で必要不可欠な技術であると考える.

また，この技術を展開することにより，アスファルト 混合物の供給エリアの改善の可能性が見いだされた．近 い将来繰り返し再生や安定供給の問題が顕在化してくる かもしれない，そうなる前に一案を講じておく必要があ る. 本研究成果が将来の社会資本整備に少しでも役立て ば幸いである。

\section{参考文献}

1）国土交通省：道路統計年報, 2016.4 .

2) 近藤紀 : アスファルトの加熱混合温度に関する一考 察，土木技術資料 10-12，pp.40-45，1968.

3) 日本道路建設業協会: 中温化(低炭素)アスファルト舗 装の手引き, 2012.4.

4) 佐々木昌平, 近藤裕章 : フォームドアスファルト混 合物の適用拡大に関寸る一考察，第 30 回日本道路会 議論文集，2013.11.

5）日本アスファルト合材協会 : アスファルト合材統計 年報, 2015 .

\title{
QUALITY CONTROL AND STEADY WIDE-AREA SUPPLY OF HIGH CONTENT OF RECYCLED ASPHALT MIXTURE
}

\author{
Kentaro KOSHI and Ryuichi IMAI
}

The amount of social capital maintenance costs is tend to be decreasing with a Japanese aging society. However the road maintenance which is the keystone of social capital maintenance is absolutely imperative. Supply of the asphalt mixture in a sustainable manner is essential into the future.

Percentage of recycled asphalt material mixtures in the total asphalt production reached approximately $75 \%$ in recent years. There are concerns over the compromised quality due to multiple recycling. Existing pavements are a social capital stock and valuable resource and they need to be recycled with ensuring quality continually.

The quantities of asphalt mixtures produced for the road pavement material have been decreased year by year with the reduction of the investment in maintenance. There are rising concerns over the stable supply of asphalt mixture throughout Japan.

This report presents the outline of the future direction by introducing foaming technologies to ensure the quality of Recycled asphalt mixture and to expand supply area by extending its usable time. 